\section{Hepatocellular carcinoma mutation}

SIR - In hepatocellular carcinoma (HCC), mutations within the p53 gene occur selectively at the third position of codon 249 (refs 1,2), unlike other human cancers where many different codons have been involved (ref. 3 and references therein). The patients in refs 1 and 2 came from areas of the world (South Africa and Qidong province of China) where there is a high exposure to hepatitis $B$ virus (HBV) and potentially a high exposure to aflatoxin $B_{1}$. It has been suggested that aflatoxin $B_{1}$, is responsible for the observed mutations ${ }^{1,2}$, but all patients who carried p53 mutations had been or were infected with $\mathrm{HBV}$. HBV infection could have been the cause of these p53 mutations, or more likely, the interaction between HBV and aflatoxin $B_{1}$ could be the necessary prerequisite for the generation of these changes in codon 249. It is thus of great interest to determine whether codon 249 mutations occur in people with HCC who have not been exposed either to HBV or to high levels of aflatoxin $B_{1}$, or have been exposed to HBV in the absence of aflatoxin $\mathbf{B}_{1}$.

We have screened 16 HCC DNA samples, from patients whose demographic details are listed in the table, for mutations at codon 249 of the p53 gene. Any changes to the second or third bases of codon 249 in exon 7 of the p53 gene result in the abolition of a restriction site for the enzyme HaeIII (ref. 2). We have combined the polymerase chain reaction

(PCR) with restriction analysis to study possible mutations of this codon in our HCC samples. Oligonucleotide primers (upstream 5'-TCTCCTAGGTTGGCTCTGACT-3' and downstream 5'-TCCTGACCTGGAGTCTTCCAG-3') were used to amplify a 125-base-pair fragment containing all of exon 7 and part of the flanking introns ${ }^{4}$. We carried out PCR on 100-200 ng of HCC DNA using 50 pmol of each primer, $2 \mathrm{U}$ Taq polymerase (Promega) in $1 \times$ Taq polymerase buffer (Promega) in a total volume of $50 \mu \mathrm{l}$. We performed 30 cycles at $94{ }^{\circ} \mathrm{C}$ for $30 \mathrm{~s}, 55^{\circ} \mathrm{C}$ for $30 \mathrm{~s}$ and $72{ }^{\circ} \mathrm{C}$ for $30 \mathrm{~s}$. The products were run through $1 \%$ Seakem ME (FMC) $+2 \%$ NuSieve GTG (FMC) agarose gels and stained wih ethidium-bromide.

The 125-base-pair fragments containing exon 7 were excised from the gel and eluted from the agarose by centrifugation ${ }^{5}$. We added $\mathrm{MgCl}_{2}$ to the eluate to find concentration of $10 \mathrm{mM}$ and precipitated DNA by addition of two volumes of ethanol and leaving at $-20{ }^{\circ} \mathrm{C}$ overnight

The DNA was pelleted by centrifugation for $15 \mathrm{~min}$, washed once with $70 \%$ ethanol, desiccated and resuspended in $7 \mu \mathrm{l} 10 \mathrm{mM}$ Tris, $1 \mathrm{mM}$ EDTA, pH 8 . These fragments were then restricted

DNA FROM PATIENTS WITH HEPATOCELLULAR CARCINOMA

\begin{tabular}{lllll}
\hline Ethnic & Cirrhosis Histology Grade & $\begin{array}{l}\text { Predisposing } \\
\text { factor }\end{array}$ & \\
Patient Sex/Age origin & Presentation
\end{tabular}

$\mathrm{HBV}-$

$\begin{array}{lll}1 & \text { F44 } & \text { Caucasian } \\ 2 & \text { F36 } & \text { Caucasian } \\ 3 & \text { M71 } & \text { Caucasian } \\ 4 & \text { M67 } & \text { Caucasian } \\ 5 & \text { M68 } & \text { Caucasian } \\ 6 & \text { M76 } & \text { Caucasian } \\ 7 & \text { M79 } & \text { Caucasian } \\ 8 & \text { M68 } & \text { Caucasian }\end{array}$

-
-
-
+
+
+
+
+

$$
\begin{aligned}
& \text { pleo } \\
& \text { trab } \\
& \text { trab } \\
& \text { trab } \\
& \text { pseu } \\
& \text { trab } \\
& \text { trab } \\
& \text { trab }
\end{aligned}
$$

\section{pleo}

2
1
2
2
$1-3$
3
2
$2-3$

$\begin{array}{ll} & \text { early } \\ & \text { early } \\ & \text { late } \\ \text { haem } & \text { late } \\ \text { alco } & \text { late } \\ & \text { late } \\ \text { haem } & \text { late } \\ \text { haem } & \text { late }\end{array}$

\section{$\mathrm{HBV}+$}

9

10

11

12

13

14

15

16

$\begin{array}{ll}\text { M51 } & \text { Melanesian } \\ \text { M52 } & \text { Aborigine } \\ \text { M52 } & \text { Caucasian } \\ \text { M29 } & \text { Melanesian } \\ \text { M57 } & \text { Vietnamese } \\ \text { M35 } & \text { Melanesian } \\ \text { F69 } & \text { Caucasian } \\ \text { M36 } & \text { Caucasian }\end{array}$

$\begin{array}{ll}- & \text { trab } \\ + & \text { trab } \\ + & \text { trab } \\ + & \text { pleo } \\ + & \text { trab } \\ - & \text { pseu } \\ + & \text { pseu } \\ + & \text { trab }\end{array}$

\begin{tabular}{ll}
2 & early \\
1 & early \\
1 & early \\
3 & early \\
1 & late \\
2 & late \\
1 & late \\
2 & late \\
\hline
\end{tabular}

Histology is as follows: trabecular (trab), pleomorphic (pleo), pseudoglandular (pseu), fibrolamell (fibr).

Tumours were graded as follows: grade 1, well differentiated; grade 2, moderately well differentiated; grade 3 , poorly differentiated.

Haem, haemochromatosis; alco, alcoholism.

Time of presentation: early, for example, found incidentally at transplantation or screening for alpha-fetoprotein and tumour less than $2 \mathrm{~cm}$ in diameter.

Eight patients had been exposed to HBV and eight had not. None of the patients had accumulated a high exposure to aflatoxin $\mathrm{B}_{1}$. for $3.5 \mathrm{~h}$ at $37^{\circ} \mathrm{C}$ with $10 \mathrm{U}$ Hae III (Toyobo) in a final volume of $10 \mu \mathrm{l}$. The resulting digests were then electrophoresed through $1.5 \%$ Seakem ME $+2.5 \%$ NuSieve GTG agarose gels. Wild-type p53 alleles would result in cleavage by HaeIII at codon 249 , giving products of 83 and 42 base pairs using the primers indicated above. Any changes at codon 249 at position 2 or 3 